\title{
PENGARUH MATEMATIKA TERHADAP MOTIVASI DAN PRESTASI BELAJAR MAHASISWA JURUSAN AKUNTANSI UNIVERSITAS BINA NUSANTARA
}

\author{
Pariang Siagian \\ Accounting Department, Faculty of Economics and Communication, BINUS University \\ Jln. K. H. Syahdan No. 9, Palmerah, Jakarta Barat 11480 \\ parsiagian@yahoo.com
}

\begin{abstract}
For learning achievement, it is acknkowledged that there are many factors influencing such as internal motivation from students, like willingness or motivation, self discipline and another important thing is level of intelligence. The background of this research is lot of students are not able to follow the lessons well, and the effect is they face some difficulties on their academic achievement, including the areas of accounting subject loaded with mathematic or counting subject. Many students are not happy about math subject, so it makes them less of motivation to learn, and ultimately affects the achievement. Therefore, the writer is interested in conducting research presented in this paper. The factor on this research is to determine whether the influence of mathematic on learning motivation and learning achievement for the students majoring in Accounting Students of Economic hoping to improve the quality of learning process in producing quality graduates. Population on this research is all Accounting Department students, Bina Nusantara University. Research method used is parametric statistic, with purposive sampling, and in processing data is SPSS method with regression analysis tool. From the research, it is concluded 1) there is significant effect of mathematic factor to the learning motivation, and 2) there is not the significant effect of mathematic factor to the learning achievement.
\end{abstract}

Keywords: mathemathic, motivation, achievement, learning

\begin{abstract}
ABSTRAK
Untuk meraih suatu prestasi belajar, diketahui ada banyak faktor yang memengaruhi, seperti motivasi internal mahasiswa berupa kemauan atau motivasi yang kuat, disiplin diri sendiri, dan yang tak kalah penting adalah tingkat kecerdasan mahasiswa. Latar belakang penelitian adalah ada banyak mahasiswa kurang mampu dalam mengikuti dan memahami pelajaran dalam proses pembelajaran termasuk bidang pelajaran akuntansi yang sarat dengan muatan matematika atau hitungan. Banyak mahasiswa tidak atau kurang dapat mengerti dan memahami suatu materi pelajaran secara baik, sehingga motivasi belajar menjadi kurang dan akhirnya akan berpengaruh negatif terhadap prestasi belajar. Oleh karenanya, penulis tertarik melakukan penelitian yang dituangkan dalam tulisan ini. Adapun faktor yang diteliti adalah untuk mengetahui ada tidaknya pengaruh matematika terhadap motivasi dan prestasi belajar dengan studi kasus pada beberapa Mahasiswa Jurusan Akuntansi, dengan harapan dapat berguna dalam peningkatan kualitas penyelenggaraan proses pembelajaran yang pada akhirnya akan menghasilkan produk lulusan yang lebih berkualitas. Populasi penelitian adalah seluruh mahasiswa Jurusan Akuntansi, Universitas Bina Nusantara, dengan teknik pengambilan sampel dilakukan secara purposive, metode penelitian adalah statistik parametris dan pengolahan data dengan program SPSS. Dari hasil penelitian diperoleh 1) Ada pengaruh yang signifikan antara ilmu matematika dengan motivasi belajar, dan 2) Tidak ada pengaruh yang signifikan antara matematika dengan prestasi belajar.
\end{abstract}

Kata kunci: matematika, motivasi, prestasi, belajar 


\section{PENDAHULUAN}

Pendidikan adalah sebuah proses pembelajaran yang disampaikan dengan berbagai metode tertentu sehingga orang memperoleh pengetahuan dan pemahaman atas sesuatu yang dipelajari yang kemudian dapat mengubah cara bertingkah laku yang sesuai dengan kebutuhan. Oleh karenanya, proses pendidikan diharapkan mampu menghasilkan output yang berkualitas. Dari berbagai macam karakteristik calon pelajar atau mahasiswa sebagai input yang masuk dalam suatu proses pendidikan, bagaimana agar pendidikan itu mampu menghasilkan output yang baik dan berkualitas, merupakan tugas dari berbagai pihak yang berkaitan dan berkepentingan terhadap pendidikan itu sendiri tidak bisa diabaikan atau dianggap sepele. Sebab melalui penyelenggaraan pendidikan yang bermutu, seseorang bisa mendapatkan ilmu pengetahuan dan keterampilan melalui berbagai prestasi yang dapat diraih di lembaga pendidikan yang tersedia.

Menurut UU. No. 20, tahun 2003, tentang sistem pendidikan nasional:

"Pendidikan Nasional bertujuan mencerdaskan kehidupan bangsa dan mengembangkan manusia Indonesia seutuhnya, yaitu manusia yang beriman dan bertaqwa terhadap Tuhan Yang Maha Esa dan berbudi pekerti luhur, memiliki pengetahuan dan keterampilan, kesehatan jasmani dan rohani, kepribadian yang mantap dan mandiri serta rasa tanggung jawab kemasyarakatan dan kebangsaan” (UU. R.I, 2003: 30).

Kemudian dalam penyelenggaraan pendidikan, belajar merupakan suatu proses dari seseorang yang berusaha untuk memperoleh suatu bentuk perubahan, bentuk perilaku yang yang lebih baik melalui prestasi belajar yang berkualitas dan membanggakan dalam berbagai bentuk. Menurut pendapat Tirtonegoro (2001: 43) prestasi belajar adalah hasil dari pengukuran serta penilaian usaha belajar yang dinyatakan dalam bentuk angka, huruf, maupun kalimat yang dapat mencerminkan hasil yang sudah dicapai oleh setiap siswa dalam periode tertentu.

Diakui, ada banyak faktor yang memengaruhi prestasi belajar mahasiswa, dan salah satunya yang paling berpengaruh adalah kebiasaan belajar. Menurut Djaali (2007: 128), kebiasaan belajar merupakan cara atau teknik yang menetap pada diri siswa pada waktu menerima pelajaran, membaca buku, mengerjakan tugas, dan pengaturan waktu untuk menyelesaikan kegiatan. Dan kebiasaan belajar merupakan suatu cara yang dilakukan oleh seseorang secara kontinu atau berulang-ulang, dan pada akhirnya menjadi suatu kebiasaan yang positif. Kemudian, kebiasaan belajar erat hubungannya dengan keterampilan belajar yang dimiliki seseorang. Keterampilan belajar yang memadai otomatis akan membentuk kebiasaan belajar yang efektif dan efisien. Pembentukan kebiasaan belajar perlu dikembangkan karena dengan terbentuknya kebiasaan belajar dapat diperoleh prestasi atau hasil belajar yang ingin dicapai. Hasil penelitian Prastiti (Pengaruh Faktor Preferensi Gaya Belajar Terhadap Prestasi Beklajar Mahasiswa Akuntansi. Jurnal Ekonomi Bisnis (3): 230, 2009) menyebutkan bahwa tidak adanya preferensi gaya belajar terhadap prestasi yang diperoleh mahasiswa jurusan Akuntasi.

Memang diakui ada mahasiswa yang mempersepsikan dirinya sebagai sosok yang selalu memiliki kelebihan tertentu dan mendorongnya untuk meraih prestasi tertentu. Sebaliknya, yang mempersepsikan sebagai sosok yang tidak punya kelebihan apa-apa membuatnya kurang terdorong untuk berprestasi. Dengan kata lain, penilaian tentang diri kita meliputi apa yang dipikirkan dan apa yang dirasakan oleh diri kita (Rakhmat, 2003: 100). Kemudian, Pujiningsih (2004), dari hasil penelitian yang pernah dilakukan (Kemandirian Belajar dalam Meningkatkan Prestasi Mahasiswa Pendidikan Akuntansi: Jurnal Pendidikan Akutansi Indonesia (3): 12 - 18) mengatakan bahwa dengan adanya tahapan belajar seperti perencanaan, implementasi, evaluasi, dan refleksi yang dilakukan, hal tersebut dapat berpengaruh terhadap prestasi belajar. 
Matematika adalah suatu bidang studi yang mempunyai peranan penting dalam dunia pendidikan. Secara teoretis, matematika merupakan ilmu yang sangat penting dalam membentuk pola berpikir logis, rasional, dan mampu memecahkan suatu masalah secara mandiri dan bertanggung jawab. Secara luas matematika juga disebut sebagai ratu ilmu pengetahuan. Dengan kata lain, matematika merupakan sumber dari pengetahuan lainnya karena banyak ilmu pengetahuan, khususnya yang bersifat hitung-hitungan, yang dalam pengembangannya bergantung dari ilmu matematika.

Pada kenyataannya, banyak pelajar termasuk mahasiswa menganggap matematika merupakan suatu pelajaran yang sulit, sehingga cenderung mereka tidak senang mempelajarinya bahkan selalu menghindarinya. Padahal matematika membuat orang dapat berpikir logis, kreatif, tepat, efisien, dan benar. Kemampuan berpikir demikian sangatlah diperlukan dalam pengembangan ilmu pengetahuan termasuk ilmu akuntansi, karena matematika merupakan suatu sarana yang diperlukan dalam pengukuran dan penghitungan yang banyak ditemukan dalam ilmu akuntansi. Dan dalam akuntansi, banyak kaedah atau rumus matematika yang digunakan untuk memecahkan masalah yang berhubungan dengan proses akuntansi.

Ilmu akuntansi memang tidak hanya didasarkan dan dihubungkan dengan matematika, seperti dengan melihat Persamaan Dasar Akuntansi (PDA) dengan persamaan matematika, tetapi juga dengan berbagai bidang ilmu lain seperti sosial, hukum, sistem, administrasi, dan historika. Ilmu akuntansi dalam kenyataannya paling banyak mengandung atau memuat unsur dan sifat matematika. Karena dengan logika matematika, akuntansi akan lebih mudah dipelajari, dimengerti, dan dikuasai. Bahkan, andaikan semua permasalahan sosial termasuk akuntansi dapat dideskripsikan dan dikaji secara matematis dengan dalil atau rumus yang lengkap, acuan yang dimanfaatkan adalah logika matematika. Dengan demikian, semua permasalahan tersebut dapat dicari solusinya secara akurat dan lengkap.

Seperti diketahui, akuntansi merupakan sebuah sistem terpadu yang terdiri dari berbagai sub sistem yang juga dapat dilihat dalam siklus atau proses akuntansi. Dalam menggunakan perspektif logika, maka dengan dasar matematika pemahaman dogmatis ilmu akuntansi dapat diuraikan atau dijabarkan secara logika. Misalnya, logika debet dan kredit dalam membuat jurnal. Contoh, ketika aktiva/harta bertambah harus dicatat di debet, demikian sebaliknya jika berkurang dicatat di sisi kredit. Juga, sifat hutang yang bertambah dicatat di kredit dan berkurang di posisi debet. Secara umum, contoh yang menggambarkan karakterstik logika di atas memang didasarkan pada pernyataan GAAP (General Accepted Accounting Principle), namun pemahaman tersebut haruslah diterima dan didasarkan pada alasan yang ilmiah yang dapat dijabarkan secara logis berdasakan ilmu matematika.

Memang diakui, bahwa prestasi belajar mahasiswa pada dasarnya dipengaruhi oleh beberapa faktor. Namun pada dasarnya, tidak ada faktor tunggal yang dominan berdiri sendiri menentukan konsep dalam belajar. Ada yang bersifat internal, yakni berasal dari diri sendiri mahasiswa dan ada faktor eksternal, seperti lingkungan lembaga pendidikan dan keluarga yang saling berkaitan dan memengaruhi. Beberapa faktor yang berpengaruh dalam prestasi mahasiswa antara lain: dukungan lembaga pendidikan tempat belajar sebagai pembina dan tempat menuntut ilmu, suasana atau budaya rumah tangga atau keluarga, tingkat kecerdasan, dan yang terpenting adalah minat seorang mahasiswa terhadap suatu jenis pelajaran yang diikuti. Faktor minat atau motivasi ini sangat dipengaruhi oleh tingkat kecerdasan seseorang dalam mengikuti proses pembelajaran. Misalnya, jika seorang mahasiswa kurang tertarik dengan materi pelajaran yang bersifat hitungan, sudah barang tentu dia akan mengalami kesulitan mengikuti mata kuliah yang sarat bermuatan hitungan seperti ilmu akuntansi yang sarat dengan matematika keuangan sehingga berpengaruh dalam pencapaian prestasi belajar mahasiswa. Dan dalam kenyataan yang sering penulis temukan, bahwa mahasiswa yang senang dengan mata kuliah yang bersifat hitungan, relatif lebih mudah menyerap dan memahami materi pelajaran yang diajarkan. Berbeda dengan mahasiswa yang kurang meminati pelajaran yang bersifat hitungan, mereka lebih sulit memahami pelajaran sehingga motivasi kurang dan berpengaruh terhadap prestasi belajar yang mereka raih. Berdasarkan latar belakang dan identifikasi masalah di atas, maka penulis tertarik melakukan penelitian dengn judul "Pengaruh Matematika Terhadap Motivasi dan 
Prestasi Belajar Mahasiswa Jurusan Akuntansi Fakultas Ekonomi dan Komunikasi Universitas Bina Nusantara”. Berkenan dengan judul tersebut, penulis melakukan penelitian terhadap permasalahan tentang pengaruh matematika terhadap motivasi dan prestasi belajar bagi para mahasiswa.

Maksud dan tujuan yang ingin dicapai melalui penelitian dan penulisan ini adalah untuk mengetahui: (1) ada tidaknya pengaruh matematika terhadap motivasi belajar mahasiswa jurusan Akuntansi, dan (2) ada tidaknya pengaruh matematika terhadap pencapaian prestasi belajar mahasiswa jurusan Akuntansi. Sementara kegunaan tulisan ini adalah secara teoretis, bermanfaat untuk memperluas khasanah dalam pengetahuan tentang konsep pengaruh matematika terhadap motivasi dan prestasi belajar bagi mahasiswa jurusan Akuntansi, dan kepada pihak akademisi dan para peneliti sebagai sumber bacaan. Secara praktis, manfaat penelitian ini bagi peneliti dapat menambah wawasan, pengetahuan, dan pengalaman tentang permasalahan dimaksud sebagai bahan masukan dalam mengatur dan memperbaiki betapa pentingnya konsep peningkatan motivasi dan prestasi belajar. Bagi staf dosen pengajar dapat menambah masukan dalam melakukan perbaikan dan pengembangan dalam proses pembelajaran yang efisien dan efektif. Dan bagi pihak lembaga dan manajemen otoritas penyelenggara pendidikan, diharapkan sebagai masukan informasi dalam peningkatan mutu penyelenggaraan pendidikan sehingga menghasilkan produk lulusan yang berkualitas sesuai dengan permintaan dunia pekerjaan.

Selaras dengan judul dan perumusan masalah di atas, maka hipotesis atau dugaan dan jawaban sementara yang akan diuji dengan hipotesis statistik (Sugiyono, 2005: 57-58), yang mengukur berbagai elemen yang terdapat dalam penelitian ini, berupa :

Ho1: Tidak ada pengaruh signifikan antara matematika terhadap motivasi belajar mahasiswa jurusan Akuntansi.

Ha1: Ada pengaruh signifikan antara matematika terhadap motivasi belajar mahasiswa jurusan Akuntansi.

Ho2: Tidak ada pengaruh signifikan antara matematika terhadap prestasi belajar mahasiswa jurusan Akuntansi.

Ha2: Ada pengaruh signifikan antara matematika terhadap prestasi belajar mahasiswa jurusan Akuntansi.

\section{METODE PENELITIAN}

Populasi sebagai objek dalam penelitian ini adalah seluruh mahasiswa jurusan Akuntansi, Fakultas Ekonomi dan Komunikasi, Universitas Bina Nusantara. Teknik pengambilan sampling dilakukan dengan cara purporsive, kepada 65 orang mahasiswa yang duduk pada semester 3 dan 5 , yang dianggap representatif atau mewakili populasi penelitian. Untuk mendapatkan data berupa tanggapan kepada para mahasiswa tentang ketiga variabel yang diteliti, dilakukan dengan cara menyebarkan kuesioner atau daftar pertanyaan secara tertulis. Penelitian ini dilakukan pada bulan Januari 2013, periode Semester Ganjil Tahun Akademik 2012/2013. Teknis analisis dan pengolahan data dalam pengujian hipotesis menggunakan statistik parametris dengan alat (tool) analisis regresi sederhana, yang di dalamnya temasuk analisis korelasi antara variabel independen yang juga sering disebut faktor-faktor penyebab dengan variabel dependen yang sering disebut faktor-faktor akibat (Pratisto, 2009 : 91). Untuk mengetahui hasil analisis atau perhitungan dari normalitas data, dan ada atau tidak adanya pengaruh antara variabel independen dengan variabel dependen, penulis menggunakan program SPSS (Statistical Product and Service Solution). 


\section{HASIL DAN PEMBAHASAN}

\section{Pengujian Normalitas Data}

Berikut ini adalah hasil uji normalitas data dari distribusi data ketiga variabel matematika, motivasi belajar, dan prestasi belajar yang diolah dengan menggunakan metode One Sample Kolmogorov - Smirnov.

Tabel 1 Hasil Uji Normalitas Data

\begin{tabular}{|c|c|c|c|c|c|c|}
\hline \multicolumn{7}{|c|}{ Tests of Normality } \\
\hline & \multicolumn{3}{|c|}{ Kolmogorov-Smirnov $^{\mathrm{a}}$} & \multicolumn{3}{|c|}{ Shapiro-Wilk } \\
\hline & Statistic & Df & Sig. & Statistic & Df & Sig. \\
\hline $\mathrm{X} 1$ & .172 & 65 & .000 & .951 & 65 & .012 \\
\hline $\mathrm{X} 2$ & .118 & 65 & .026 & .974 & 65 & .186 \\
\hline X3 & .137 & 65 & .004 & .964 & 65 & .054 \\
\hline
\end{tabular}

\section{Interpretasi}

Dari analisis uji normalitas data, maka diperoleh hasil perhitungan bahwa nilai signifikansi untuk variabel ilmu matematika (X1), motivasi belajar (X2), dan prestasi belajar (X3) semuanya memiliki nilai hitung di bawah nilai tabel 3,14. Dengan kata lain, nilai signifikansi semuanya mendekati nol. Dengan demikian, kualitas data dianggap normal dan layak untuk diolah selanjutnya.

\section{Hasil Uji Regresi X1 terhadap X2}

Tabel 2 Hasil Penghitungan F Hitung X1 terhadap X2

\begin{tabular}{ccrccc} 
& & & & & Anova \\
\hline Model & Sum of square & \multicolumn{1}{c}{ df } & Mean square & F & \multicolumn{1}{c}{ Sig. } \\
\hline 1 Regrerssion & 53.786 & 1 & 53.786 & 7.424 & .000 \\
Residual & 456.430 & 63 & 7.245 & & \\
Total & 510.215 & 64 & & & \\
\hline Predictor X1 & & & & &
\end{tabular}

\section{Interpretasi}

Dapat dilihat nilai probabilitas (Sig) adalah 0.00 lebih kecil daripada 0,05, berarti model diterima atau dapat disimpulkan bahwa bentuk persamaan linier yang digunakan sudah tepat dan dapat dipertanggungjawabkan. Kemudian, melihat hasil perhitungan dari tabel Anova di atas, diperoleh nilai F hitung sebesar 7.424, yang selanjutnya hasil F hitung tersebut dikonsultasikan dengan F tabel, dengan jumlah $\mathrm{F}$ pembilang (variabel) 1 dan penyebut 63 dengan tarif kesalahan 5\%, dan ditemukan nilai $\mathrm{F}$ tabel adalah 2,34 lebih kecil daripada F hitung 7,245, dengan demikian model linier. Maka hipotesis Ho ditolak dan hipotesis Ha diterima, artinya ada pengaruh matematika terhadap motivasi belajar pada seluruh mahasiswa jurusan Akuntansi yang telah disurvei. Dependent Variable X2 
Tabel 3 Hasil Penghitungan t Hitung Variabel X1 terhadap X2

\begin{tabular}{|c|c|c|c|c|c|c|}
\hline & & & & & \multicolumn{2}{|c|}{ Coefficients $^{\mathrm{a}}$} \\
\hline & \multirow[t]{2}{*}{ Model } & \multicolumn{2}{|c|}{ Unstandardized Coefficients } & \multirow{2}{*}{$\begin{array}{c}\begin{array}{c}\text { Standardized } \\
\text { Coefficients }\end{array} \\
\text { Beta } \\
\end{array}$} & \multirow[t]{2}{*}{$\mathbf{T}$} & \multirow[t]{2}{*}{ Sig. } \\
\hline & & B & Std. Error & & & \\
\hline \multirow{2}{*}{1} & (Constant) & 5.346 & 2.947 & & 1.814 & .074 \\
\hline & $\bar{X} 1$ & .638 & .234 & .325 & 2.725 & .008 \\
\hline
\end{tabular}

a. Dependent Variable: $\mathrm{X} 2$

\section{Interpretasi}

Melihat hasil perhitungan tabel coefficients di atas, pada kolom unstandardized coefficients B didapat nilai konstanta sebesar 5,346, dan konstanta untuk $X$ (salinitas) sebesar 0,638, maka didapatkan persamaan regresi $\mathrm{Y}=5,346+0,634 \mathrm{X}$. Selanjutnya, dari hasil uji t yang menguji signifikansi koefisien yang menggambarkan apakah variabel independen X1 matematika berpengaruh terhadap variabel X2 motivasi belajar, dapat dilihat dari hasil perhitungan $\mathrm{t}$ hitung berikut. Menurut hasil t tabel, dengan derajat bebas 63 sampel dengan 2 sisi dengan tingkat signifikansi 0,05 , menunjukkan nilai t tabel adalah 2,010 lebih kecil dari nilai t hitung 2,725. Jadi dapat disimpulkan, bahwa hipotesis Ho ditolak dan hipotesis Ha diterima, artinya variabel matematika berpengaruh secara nyata atau signifikan terhadap motivasi belajar mahasiswa akuntansi yang diteliti.

\section{Hasil Uji Regresi X1 terhadap X3}

Tabel 4 Hasil Penghitungan F Hitung X1 terhadap X3

\begin{tabular}{llcrccc}
\hline & & & & & Anova \\
\hline 1 & Megrerssion & Sum of square & \multicolumn{1}{c}{ df } & Mean square & F & Sig. \\
Residual & 1.928 & 1 & 1.928 & .468 & .497 \\
Total & 259.826 & 63 & 4.124 & & \\
\hline
\end{tabular}

Predictor X1

Dependent Variable X3

\section{Interpretasi}

Dari tabel Anova di atas, dilihat nilai probabilitas (Sig) adalah 0.497 lebih besar daripada 0,05, berarti model tidak dapat diterima, atau dapat disimpulkan bahwa bentuk persamaan linier yang digunakan tidak tepat. Dengan kata lain, dengan mengatahui hasil perhitungan dari tabel Anova di atas, dengan diperoleh nilai $\mathrm{F}$ hitung sebesar 0.468 , yang selanjutnya hasil $\mathrm{F}$ hitung tersebut dikonsultasikan dengan nilai $\mathrm{F}$ tabel, dengan jumlah $\mathrm{F}$ pembilang (variabel) 1 dan penyebut 63 dengan tarif kesalahan 5\%, dan ditemukan nilai $\mathrm{F}$ tabel adalah 2,34 lebih besar dari nilai $\mathrm{F}$ hitung sebesar 0,468. Maka, hipotesis Ho diterima dan hipotesis Ha ditolak. Oleh karena itu, disimpulkan bahwa tidak ada pengaruh variabel matematika terhadap variabel prestasi belajar pada mahasiswa jurusan Akuntansi yang telah diteliti. 
Tabel 5 Hasil Penghitungan t Hitung X1 terhadap X3

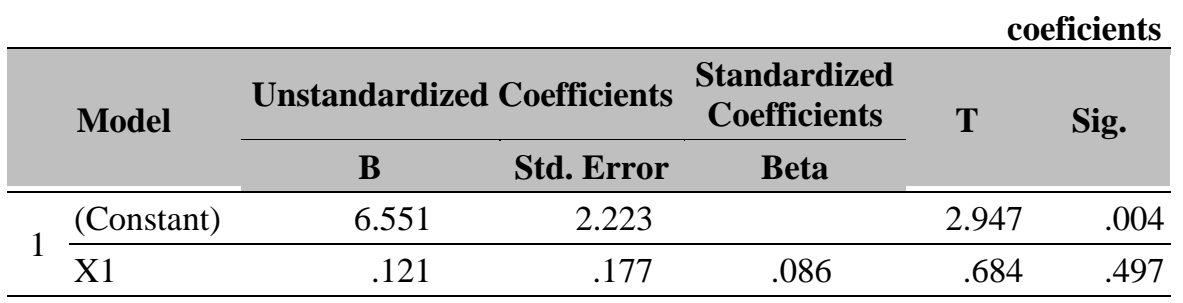

a. Dependent Variable: X3

\section{Interpretasi}

Hasil penghitungan tabel coefficients di atas memperlihatkan, bahwa pada kolom unstandardized coefficients B, didapat nilai konstanta sebesar 6,551, dan konstanta untuk X (salinitas) sebesar 0,121. Maka, didapatkan persamaan regresi $\mathrm{Y}=6,551+0,121 \mathrm{X}$. Kemudian, dari hasil uji $\mathrm{t}$ yang menguji signifikansi koefisien yang menggambarkan jika variabel independen X1 matematika berpengaruh terhadap prestasi belajar, dapat dilihat dari hasil perhitungan $\mathrm{t}$ hitung berikut. Menurut hasil t tabel, dengan derajat bebas 63 sampel dengan 2 sisi dengan tingkat signifikansi 0,05 , menunjukkan nilai t tabel sebesar 2,010 lebih besar dari nilai t hitung sebesar 0,684. Dengan demikian, dapat disimpulkan bahwa hipotesis Ho diterima dan Ha ditolak. Artinya, variabel matematika tidak berpengaruh secara nyata atau signifikan terhadap variabel prestasi belajar mahasiswa akuntansi yang diteliti.

\section{SIMPULAN}

Dari uraian di atas, disimpulkan bahwa secara umum prestasi belajar setiap orang dapat dipengaruhi oleh berbagai faktor, di antaranya motivasi, disiplin diri sendiri, lingkungan sosial, rumah tangga, dan lembaga pendidikan tempat seseorang menggali ilmu. Serta yang tak kalah penting adalah kebiasaan atau tradisi belajar untuk selalu rajin belajar. Kemudian menurut penelitian yang dilakukan, diperoleh simpulan bahwa faktor matematika berpengaruh terhadap motivasi belajar mahasiswa, namun unsur matematika tidak memengaruhi prestasi belajar yang diraih oleh mahasiswa jurusan Akuntansi. Hal ini dapat diakibatkan oleh berbagai faktor lain, seperti beberapa mata kuliah yang didapat dalam penyelenggaraan perkuliahan bersifat teoretis yang bukan berupa hitungan dalam bentuk angka-angka. Dengan kata lain, bukan mata kuliah kuantitatif saja yang menentukan tingkat prestasi akademik mahasiswa jurusan Akuntansi. Walaupun diakui, bahwa banyak mata kuliah yang membutuhkan analisis bersifat logika dan tingkat kecerdasan dalam berhitung yang menuntut daya nalar dan logika berpikir dalam mempelajari dan menyelesaikan berbagai kasus dan soal beberapa mata kuliah dimaksud, khususnya yang sarat dengan angka-angka yang bersifat hitungan.

Dari hasil analisis di atas, dalam rangka peningkatan kemauan atau motivasi belajar mahasiswa jurusan Akuntansi di kemudian hari, diharapkan agar dalam proses seleksi dapat lebih selektif memerhatikan nilai matematika yang sesuai dalam rapor, NEM, dan ijazah sekolah dari calon mahasiswa yang mendaftar. Kemudian, dalam meningkatkan prestasi belajar, perlu memerhatikan berbagai faktor lain yang bersifat internal seperti kemauan atau motivasi yang kuat dan tingkat disiplin diri sendiri yang tinggi dari para mahasiswa. Sementara di sisi lain, berupa faktor eksternal adalah budaya disiplin yang diterapkan oleh lembaga pendidikan, kompetensi staf pengajar yang mumpuni untuk dapat memotivasi para mahasiswa agar belajar giat dan berprestasi tinggi, serta berbagai perangkat fasilitas pendukung lainnya, sehingga kualitas output yang dihasilkan tepat guna yakni sesuai dengan kualifikasi kebutuhan berbagai user atau dunia kerja. 


\section{DAFTAR PUSTAKA}

Djaali. (2007). Psikologi Pendidikan. Jakarta: Bumi Aksara.

Prastiti, S. D. (2009). Pengaruh Faktor Preferensi Gaya Belajar Terhadap Prestasi Belajar Mahasiswa Akuntansi. Jurnal Ekonomi Bisnis. No.3 (hal.230). Fakultas Ekonomi. Universitas Negeri Malang.

Pratisto, A. (2009). Statistik Menjadi Mudah Dengan SPSS 17. Jakarta: Elex Media Komputindo.

Pujiningsih, S., Mustikawati, I. (2004). Kemandirian Belajar Dalam Meningkatakan Prestasi Mahasiswa Pendidikan Akuntansi. Jurnal Pendidikan Akuntansi Indonesia. Vol. III. (hal.1218). Universitas Negeri Yogyakarta.

Rakhmat, J. (2003). Psikologi Komunikasi. Bandung: Remaja Rosdakarya.

Republik Indonesia. 2003. Undang-Undang No. 2003 tentang Sistem Pendidikan Nasional. Bandung: Citra Umbara.

Slamet. (2003). Belajar Dan Faktor-Faktor Yang Mempengaruhinya. Jakarta: Rineka Cipta.

Sugiyono. (2002). Metodologi Penelitian Bisnis. Bandung: Alfabeta.

Sukmadinata, N. S. (2003). Landasan Psikologi Proses Pendidikan. Bandung: Remaja Rosdakarya.

Surakhmad, W. (2003). Pengantar Interaksi Belajar-Mengajar. Bandung: Tarsito.

Tirtonegoro, S. (2001). Penelitian Hasil Belajar Mengajar. Surabaya: Usaha Nasional.

Weygandt, J. J. Kieso and Kimnel. 2009. Financial Accounting. $8^{\text {th }}$ Edition. New York: John Wiley \& Son. 